\title{
DIAGNOSTICS OF PROBLEMS OF REPRODUCTION OF PROFESSIONAL POTENTIAL OF THE STATE AND MUNICIPAL MANAGEMENT AS A PRECONDITION OF ITS SYSTEM RENOVATION
}

\author{
Viktor M. Zaharov ${ }^{*}$, Oleg V. Bykhtyn ${ }^{2}$, Ivan I. Gulyaev ${ }^{3}$, Natal'ya V. Shevchenko ${ }^{4}$, Maksim V. Selyukov ${ }^{5}$, Larisa \\ N. Shmigirilova ${ }^{6}$ \\ ${ }_{1,2,3,4,5,6}$ Belgorod State University, 85 Pobedy Street, Belgorod, the Belgorod region, 308015, Russian Federation. \\ Email: *russia@prescopus.com
}

Article History: Received on $21^{\text {st }}$ August 2019, Revised on $29^{\text {th }}$ September 2019, Published on $06^{\text {th }}$ November 2019

\begin{abstract}
Purpose of the study: This article deals with the renovation system of reproduction of professional potential and provides a definition of this concept.

Methodology: The study uses the methods of dialectical contradiction, the ascent from the abstract to the concrete, structural-functional and comparative analysis, theoretical modeling and generalization. Primary sociological information is collected through a questionnaire survey, document analysis, free interview, and observation. Methods of grouping and classification of empirical data, qualitative analysis of factors are also used.

Results: the renovation system of reproduction of the professional potential of a state municipal government involves the diagnosis of its problems with the aim of determining the ways of their resolution. The conducted diagnostics identified six groups of actual problems, namely lack of professionalism, the disintegration of indicators of individual and institutional efficiency, the imperfect system of training and advanced training of managerial personnel, the weak motivation of their professional development, inefficient use of professional potential, and passive personnel policy
\end{abstract}

Applications of this study: This research can be used for the universities, teachers, and students.

Novelty/Originality of this study: In this research, the model of Diagnostics of Problems of Reproduction of Professional Potential of the State and Municipal Management as a Precondition of Its System Renovation is presented in a comprehensive and complete manner.

Keywords: Renovation System, Professional Potential, Public Service, Municipal Service.

\section{INTRODUCTION}

One of the priorities in the development strategy of the Russian society is the introduction of effective mechanisms of government. The activity of state authorities at the present stage shows no high efficiency, which is manifested in a protracted economic crisis, a reduction in production volumes, a deterioration in the quality of life, a drop in wages. Low management efficiency causes citizens to distrust the institutions of state power, the deterioration of its image in the international arena. In the World Bank's Government Effectiveness rating, which takes into account the quality of state policy and the services provided, as well as the sustainability of the state's intentions to improve this quality, Russia had $35 \%$ in 2014 with a maximum efficiency value of 100\%. The same for China was 55\%, Georgia - 65\%, and Germany $95 \%$. Russia ranks 103 of 144 countries in terms of competitiveness of state institutions, as per the EEF 2015-2016.

Until recently, the problem of improving the activities of state bodies was not particularly acute and was neglected. Currently, the country's leadership is seriously concerned about this problem and is ready to take the necessary actions to address it.

The success of the government depends on many factors - social and political, internal and external, organizational and personnel. They include, among all, the factor of professionalism of public servants; it is favored by researchers in ensuring the effectiveness and quality of work of public bodies. The professionalism of civil servants is the key to effective, high-quality management activities, while lack of professionalism leads to wrong decisions and inefficient management.

If the professionalism of personnel serves as a guarantee of effective management, then the current ineffective management is explained by the insufficient professionalism of the currently working personnel. In this case, there are various options for explaining this situation. Firstly, the management staff does not have the necessary and sufficient professional potential and, accordingly, it is not manifested in the form of real professionalism. Secondly, there is a professional potential, however, for some reason, it remains unclaimed. Thirdly, there is potential but there is no corresponding motivation for its implementation. Fourth, all the "components" are available - the potential itself, its relevance, motivation, however, there may be no organizational conditions, due to which their living integrity is formed. We shall note that all these options have one generic basis - the reproduction of professional potential, which integrates them in the form of system elements and appears itself as a specific system. It is the systemic nature of the reproduction of the professional potential of management personnel that ensures management efficiency, and, on the contrary, the nonconsistency inherent in the current reproduction processes is the main cause of the low professionalism of management personnel and, as a result, inefficient management. 
Thus, it is necessary to form this system, or rather to reconstruct it using the elements that have preserved viability. At the same time, reconstruction does not mean restoration, but renovation (renewal) of the system of reproduction of the professional potential of public administration. The renovation system of reproduction provides for the improvement of the quality of management training, continuous development and the comprehensive implementation of their professional potential.

Ensuring high efficiency of public administration is a precondition for achieving the same efficiency in municipal government and, conversely, the managerial achievement in the municipal sphere is integrated into the success of management at the state level. This circumstance allows us to put in one "package" the problem of the systemic renovation of the reproduction of the professional potential of both state and municipal government.

Summarizing the above, we can state that the relevance of the research is due to the need to form a renovation system for the reproduction of the professional potential of state and municipal government as the most important prerequisite for its improvement, the conditions for ensuring high efficiency and quality.

\section{LITERATURE REVIEW}

There is a significant array of publications related to our research topic. We can distinguish several groups in this array.

The first group of studies (publications) relates to the disclosure of the contents of the personnel potential, the personnel structure of state and municipal management. This group of studies also includes publications covering the issues of professionalism of state and municipal servants. It is also necessary to consider studies on individual aspects of human potential - social potential, social and professional potential, and intellectual potential (Abakarov, D. K. 2013; Aleksandrov, O. 2015; Babincev, V. P., \& Sycheva, M. I. 2012). These studies, of course, emphasize the specific features and regularities of potentials, however, at the same time, some research results also have a universal (generic) value. Thus, the studies on social potential reveal enough the group level of potential; the studies on social and professional potential reveal the unity of its social and professional "components", their interdependence and interconnection; the studies on intellectual potential reveal patterns of human reproduction, including professional ones (Nikitina, A. 2013; Paramonov, A. P. 2013; SHamahov, V. 2012; Stepanova, T. 2013).

The competency-based approach found its wide application in the study of the professional development of state and municipal government personnel. Within the framework of this approach, professional competencies are actively explored (Bazhin, I. I. 2013; Karceva, T. 2013; Kolesov, E. 2013; Krivoshapka, I. 2014).

The third group includes studies revealing the problems of the effectiveness of state and municipal government, the conditions and ways of increasing managerial effectiveness and efficiency. (Kudryavceva, E. I. 2013; Litvinceva, E. A., \& Pereverzina, O. 2013; Manuil'skij, M. 2016; Marchenko, I. 2015).

A review of the scientific literature on the research topic leads to the following conclusions.

First, the issues of human potential, its structure, and reproduction are rather fully investigated. There is no shortage of publications covering various aspects of personnel policy and its implementation.

Secondly, the competency-based approach to the training and advanced training of managerial personnel, the assessment of their professional potential has become widespread.

Third, there is a clear lack of publications that reveal the social content of the professional potential, the patterns of its reproduction and implementation. There are practically no studies examining the role of professional potential and its use in increasing the effectiveness of state and municipal government.

\section{METHODS}

The study uses the methods of dialectical contradiction, the ascent from the abstract to the concrete, structural-functional and comparative analysis, theoretical modeling and generalization. Primary sociological information is collected through a questionnaire survey, document analysis, free interview, and observation. Methods of grouping and classification of empirical data, qualitative analysis of factors are also used.

The empirical sources of the research are the regulatory, reference, and analytical documents of the federal, regional, and municipal authorities on personnel policy and reproduction of personnel potential;

In addition, the materials of the research "Formation of the system of reproduction of the professional potential of regional management personnel" - an expert study in five regions of the Central Federal District of the Russian Federation in 20132014 (127 state employees were surveyed), as well as materials of the "Study of the corporate culture of civil servants of Belgorod region" conducted in 2016 in Belgorod (808 civil servants interviewed) were used. The data of the sociological research "Assessment of the effectiveness of the municipal personnel policy of the city of Belgorod" conducted in Belgorod in 2014 (1100 municipal employees involved) were used.

\section{RESULTS}

The concept of "renovation system" has so far not been used in relation to the reproduction of the professional potential of 
state and municipal employees, thus it needs both clarification and conceptualization. Systematic renovation of the reproduction of professional state and municipal management in the region involves the determination of the system bases of this process, including reproduction models, system-forming features, and principles of the formation of a system model.

The renovation system of reproduction of professional potential is a renewed system of reproduction practices through the selection and integration of their systemic and innovative elements and characterized by a dominant focus on ensuring the effectiveness of management activities, preventive orientation, metasystem, competency-based approach to the assessment and development of professional potential. The reproduction of professional potential as an object of systemic renovation integrates its quantitative, dynamic, informative, qualitative, functional, and target aspects. The objective basis of the renovation system is the social dynamics of modern management, which is characterized by contradictions between a) the need for effective management and the inability to such management; b) the need for conceptualization of management and day-to-day management practices; c) creative attitudes of staff and conservative organizational structures; d) management virtualization trends and modern organizational structures; e) trends of unification and uniqueness; e) trends towards massification and individualization of products of management activities; $\mathrm{g}$ ) the role of a citizen, on the one hand, and an employee, on the other; $h$ ) the multidimensionality of professional activity resources and the complexity of their identification; i) investments in professional growth and their results (returns); and $\mathrm{j}$ ) traditional (qualification) and new (functional) approaches. To become a real source of development, these contradictions must be reflected in an activity format, that is, in the form of a specific concept, project of actions and technologies. Such activity reflection is carried out within the framework of the competence approach, which allows determining the quality (competence) parameters of professional potential: focus on efficiency, practice-oriented, conceptual, integrated, applicability, creativity, processability, humanistic nature, continuity, and boundedness.

The renovation system of reproduction of the professional potential of a state municipal government involves the diagnosis of its problems with the aim of determining the ways of their resolution.

Our interregional expert analysis in the regions of the Central Federal District allowed us to identify six groups of problems of reproduction of the professional potential of regional management. These are 1) insufficient professionalism of managerial personnel; 2) weak correlation between the indicators of the professional potential of managerial personnel, on the one hand, and the indicators of the effectiveness and efficiency of regional management, on the other; 3) an imperfect system of training and advanced training of managerial personnel; 4) low level of motivation of state and municipal servants; 5) irrational use of the professional potential of regional management; and 6) ineffective personnel policy.

The advantages and disadvantages of modern managers, including the staff of regional and municipal management, are evaluated according to the criteria for their effective and efficient fulfillment of managerial duties. In this regard, expert assessments of the level of adequacy of professional competencies of regional management personnel deserve attention for the effective performance of their duties (interregional expert survey - 2014). The estimates were as follows: yes - 29.4\%, more likely yes than no $-34.9 \%$, more likely no than yes $-20.6 \%$, no $-2.4 \%$. (Every eighth of the surveyed experts found it difficult to answer the question). In general, every fourth of the respondents considers the level of competence insufficient. Experts from the Oryol region assess the level of professional potential as high enough, experts from the Lipetsk and Belgorod regions - as a medium, and experts from the Bryansk and Kursk regions - as below from the average. So far, we had considered the problem of professionalism of management personnel in terms of their real management activities. It can be assumed in this case that insufficient professionalism is due to a lack of competence (professional) potential. This assumption is confirmed by the results of our sociological and statistical analysis. Thus, the problem of shortage of qualified personnel in the system of state administration was determined by a total of $72.5 \%$ of the polled civil servants of the Belgorod region (while $12.5 \%$ assessed it as extremely significant). Eleven percent of respondents see nothing important in this problem, and only $7.3 \%$ answered that there is no such problem.

The availability of professional potential of regional management bodies is noted by $53.5 \%$ of the participants of the interregional expert survey, a third of the experts $(29.1 \%)$ indicate insecurity.

The third part of the participants of the interregional expert survey (34.9\%) declared its awareness of the system of reproduction of professional potential; nearly the same share (31\%) gave an evasive, general answer; $28 \%$ of experts indicated the absence of such a system. Such ambiguous and contradictory assessments may indicate either a lack of consistency in regional practices of reproduction of professional potential, or a lack of awareness among respondents about the existing reproduction system, or divergence in the interpretation of the concept of the reproduction system of professional potential, its reduction to individual constituent elements. Given that the survey involved experts who were directly engaged in the process of reproducing the professional potential of regional management, the second option is discarded, and the first and third options can be considered reliable. At the same time, there is most likely no reproduction system as such, which was reflected in the skeptics' estimates. At the same time, there are more or less institutional phenomena in the practice of reproduction of professional potential that is associated with the ideas about the system of reproduction and gives grounds for optimistic statements. 
Analysis of the problems of reproduction of professional potential reveals one paradoxical situation, which, on the one hand, has a deficiency (deficit) of professional potential, and on the other hand, its irrational use (which hides, in fact, it's surplus). More than half of the polled civil servants of the Belgorod region $(51.1 \%)$ noted that their personal potential is incompletely fulfilled. It should be noted that, as the respondents believe, the degree of fulfillment of personal potential among employees under 30 is quite lower: $66.2 \%$ indicated that their personal potential is partially fulfilled. While among employees aged 60 and over, $100 \%$ of respondents say that their personal potential is completely fulfilled. Almost half of the respondents indicated that they spend their working hours not efficiently enough.

Irrational use of professional potential is also confirmed by the results of other studies. Thus, more than half of the experts $(52.8 \%)$ who participated in the interregional survey noted that the professional potential is used "half" or "insufficiently" (only $29.9 \%$ of experts expressed the opposite opinion).

The results of the study confirm the assumption of a weak link between the indicators of the professional potential of management personnel, on the one hand, and the indicators of the effectiveness and efficiency of regional management, on the other. Only half of the experts surveyed stated unequivocally that the continuous development of professional competencies of management personnel directly affects management efficiency.

\section{CONCLUSION}

On the basis of the available data, we can argue that the majority of state and municipal employees of the Belgorod region are characterized by an individually adaptive behavior strategy. First of all, they focus on self-fulfillment, and secondly on solving social and state problems. They lay great emphasis simultaneously on adapting to the situation rather than on its change.

Analysis of the problems of reproduction of professional potential reveals one paradoxical situation, which, on the one hand, has a deficiency (deficit) of professional potential, and on the other hand, its irrational use (which hides, in fact, it's surplus).

The "most problematic" elements of the reproduction of professional potential are "forecasting professional potential" and "providing conditions for the effective use of the professional potential of managerial personnel". Experts attributed the main problems to the professional training of managers: the ineffectiveness of the link of educational institutions with employers and managers of various management sectors; poor practical training; lack of an effective selection system for training future managers; and low qualifications of teachers and professionals who provide training.

The development of the professional potential of state and municipal employees is possible under organizational, personnel, informational, analytical, and technological conditions.

1. The provision of organizational conditions for the professional development of personnel of regional management is conducted in the following areas: provision of the effectiveness of the activities of representative bodies of power; improvement of the system of executive bodies; development of local government. At the same time, the process of forming and developing organizational capacity is characterized by a number of unaddressed problems: the lack of a scientifically based concept and program for organizational development; imperfect methodology for assessing the activities of executive and administrative bodies at the municipal level; low efficiency of implementation of outsourcing; low efficiency of interaction between state and municipal authorities; and lack of inter-municipal interaction mechanisms and the practice of creating project structures.

2. Personnel conditions include the formation of unified personnel policy in the region; improvement of the qualitative composition of the staff; introduction of a payroll system by results; an increase of the prestige of state and municipal service and improvement of the organizational structures, methods, and technologies of personnel activity. Further development of personnel support for the systemic renovation of the reproduction of professional potential includes: improvement of planning and human resource management, completing the process of implementing the incentive system for state and municipal employees based on the performance indicators of their activities.

3. Information and analytical support for the development of the professional potential of state and municipal servants is carried out in the following areas: effective formation and use of regional information resources; provision of wide, free access thereto; provision of citizens with socially significant information and the development of independent, sociallyoriented media; personal computerization and informatization of authorities, regional state institutions and organizations.

4. Technological support for the development of the professional potential of state and municipal servants is conducted in the following areas: implementation of administrative reform in the region; technologization of local government; reforming of public finances. At the same time, the following problems remain unaddressed: the administrative regulations of state services and state functions have not been fully approved; lack of practical use of electronic regulations of state functions and state services; a relatively low level of technological culture of management personnel; lack of system for introducing modern planning and forecasting technologies into the practice of state and municipal management; control over the execution of decisions is not always effective. 


\section{REFERENCES}

1. Abakarov, D.K., 2013. Faktornye osnovaniya kachestva professionalizma gosudarstvennyh sluzhashchih. Gosudarstvennaya sluzhba, 2: 48-51.

2. Aleksandrov, O., 2015. Optimizaciya sostava gosudarstvennoj sluzhby. Gosudarstvennaya sluzhba, 3: 69-72.

3. Babincev, V.P., Sycheva, M.I., 2012. Formirovanie i razvitie professional'noj kompetentnosti menedzherov: social'no-tekhnologicheskij aspekt. Sovremennye problemy nauki i obrazovaniya, 3: 405-408.

4. Bazhin, I.I., 2010. Indikatory effektivnosti social'nyh mekhanizmov regional'noj vlasti. Gosudarstvennaya sluzhba, 3: 53-57.

5. Bazhin, I.I., 2013. Kachestvo obrazovaniya - resurs povysheniya effektivnosti organov vlasti. Gosudarstvennaya sluzhba, 1: 45-48.

6. ZHil'cov, V.I., 2012. Effektivnost' obucheniya gosudarstvennyh grazhdanskih sluzhashchih RF za rubezhom. Gosudarstvennaya sluzhba, 2: 14-16.

7. ZHilyaev, A., 2012. Raschety social'noj effektivnosti rukovodyashchej deyatel'nosti. Gosudarstvennaya sluzhba, 4: 31-33.

8. Karceva, T., 2013. Ocenka effektivnosti deyatel'nosti rukovoditelya: social'noe orientirovanie. Gosudarstvennaya sluzhba, 2: 107-109.

9. Kolesov, E., 2013. Ocenka kadrovogo potenciala organov mestnogo samoupravleniya. Gosudarstvennaya sluzhba, 6: 109-111.

10. Krivoshapka, I., 2014. Ocenka effektivnosti upravleniya: usloviya zadachi i gotovye otvety. Effektivnoe antikrizisnoe upravlenie, 6 (87): 34-40.

11. Kudryavceva, E.I., 2013. Psihologiya upravlencheskoj effektivnosti v usloviyah raspredelennogo upravleniya. Upravlencheskoe konsul'tirovanie, 9(57): 22-31.

12. Kungurceva, G.F., 2012. Intellektual'nyj potencial kak bazovyj resurs razvitiya sistemy upravleniya sovremennym obshchestvom, Ph.D. thesis.

13. Litvinceva, E.A., Pereverzina, O., 2013. Rotaciya kak tekhnologiya povysheniya effektivnosti deyatel'nosti grazhdanskih sluzhashchih. Gosudarstvennaya sluzhba, 3: 41-44.

14. Manuil'skij, M., 2016. Rossijskij chinovnik: sociologicheskij analiz zhiznennogo mira gosudarstvennyh i municipal'nyh sluzhashchih. Gosudarstvennaya sluzhba, 1: 88-90.

15. Marchenko, I., 2015. Neobhodimost' modernizacii raboty s rezervom. Gosudarstvennaya sluzhba, 3: 63-68.

16. Nikitina, A., 2013. Professional'nye kompetencii gosudarstvennyh grazhdanskih sluzhashchih v tradicionnyh i innovacionnyh praktikah: sociologicheskij analiz. Gosudarstvennaya sluzhba, 2: 44-46. https://doi.org/10.1080/00094056.2013.757527

17. Novikov, V.G., 2011. Vosproizvodstvo social'no-professional'nogo potenciala agrarnyh kadrov Rossii, Ph.D. thesis.

18. Paramonov, A.P., 2013. Social'nyj potencial voinskih kollektivov. Gosudarstvennaya sluzhba, 1: 108-110.

19. Raven, Dzh., 2002. Kompetentnost' v sovremennom obshchestve: vyyavlenie, razvitie i realizaciya. Kogito-Centr, pp. 400.

20. Soboleva, T., 2008. Metodika formirovaniya kadrovogo rezerva. Sluzhba kadrov i personal, 1: 79-84.

21. Spenser, S.M., 2009. Kompetencii na rabote. Modeli maksimal'noj effektivnosti raboty. GIPPO, pp. 384.

22. Stepanova, T., 2013. Evropejskij opyt podgotovki specialistov po gosudarstvennomu upravleniyu. Gosudarstvennaya sluzhba, 2: 97-99.

23. Tavokin, E., 2010. Kachestvo upravlencev dlya kachestva upravleniya. Gosudarstvennaya sluzhba, 1: 42-46.

24. Turchinov, A.I., Magomedov, K.O., 2010. Kadrovyj potencial gosudarstvennoj grazhdanskoj sluzhby: duhovnonravstvennye problemy. MAKS-Press, pp. 122.

25. Uiddet, S., Holliford, S., 2008. Rukovodstvo po kompetenciyam. 3-izd. per s anglijskogo. Izdatel'stvo GIPPO, pp. 228.

26. Shamahov, V., 2012. Novoe kachestvo podgotovki gosudarstvennyh i municipal'nyh sluzhashchih. Gosudarstvennaya sluzhba, 3: 53-56. 